\title{
PENGARUH PEMBERIAN TEPUNG INDIGOFERA TERHADAP KECERNAAN BAHAN KERING, BAHAN ORGANIK, DAN SERAT KASAR PADA PEDET FRIES HOLSTEIN (FH)
}

\section{INFLUENCE OF FEEDING INDIGOFERA POWDER ON DRY METTER DIGESTIBILITY, ORGANIC METTER DIGESTIBILITY, CRUDE FIBER DIGESTIBILITY OF CALF FRIES HOLSTEIN (FH)}

\author{
M Hesa Ali Gofur1a, D Sudrajat'1, B Malik
}

1ProgramStudi Peternakan Fakultas Pertanian Universitas Djuanda Bogor, Jl. Tol Ciawi No. 1, Kotak Pos 35 Ciawi, Bogor 16720.

aKorespondensi: Deden Sudrajat, E-mail: deden.sudrajat@unida.ac.id

(Diterima oleh Dewan Redaksi: 20-10-2020)

(Dipublikasikan oleh Dewan Redaksi: 30-04-2021)

\begin{abstract}
This reasearch was aim to review about the Influence of input indigofera powder on dry matter digestibility, organic metter digestibility, and crude fiber digestibility of calf. This research use Randomized Complete Design (RAL) with treatment are: R0) concentrate $40 \%+$ forage $60 \%$, R1) forage $60 \%+(5 \%$ indigofera powder $+35 \%$ concentrate $)$, R2) forage $60 \%+(10 \%$ indigofera powder $+30 \%$ concentrate. Result of this research calf that's feeds indigofera powder did not differ markedly $(\mathrm{P}>0,05)$.
\end{abstract}

Key Word: Indigofera Powder, calf, Dry meter digestibility, Organic metter digestibility, crude fiber digestibility

\begin{abstract}
ABSTRAK
Penelitian ini bertujuan untuk mengkaji pengaruh tepung indigofera yang diberikan ke pedet terhadap KCBK, KCBO, dan SK. Penelitian menggunakan RAL dengan perlakukan sebagai berikut: Ro) Kosentrat 40\%+Hijauan 60\% R1) Hijauan $60 \%+(5 \%$ tepung indigofera $+35 \%$ konsentrat R2) Hijauan $60 \%+(10 \%$ tepung indigofera $+30 \%$ konsentrat . Hasil penelitian mengungkapkan bahwa pedet $\mathrm{FH}$ yang diberi ransum Konsentrat+Hijauan (rumput gajah)+ tepung indigofera tidak berpengaruh nyata $(\mathrm{P}>0,05)$.

Kata kunci: Tepung indigofera, Pedet, KCBK, KCBO, Serat Kasar

M Hesa Ali Ghopur, D Sudrajat, B Malik. 2021. Pengaruh Tepung Indigofera Terhadap KCBK, KCBO, dan SK Pada Pedet Frisien Holstein (FH). Jurnal Peternakan Nusantara 7(1):: 1-6
\end{abstract}

\section{PENDAHULUAN}

Pedet adalah anak sapi yang baru lahir sampai ditandakan birahi pertama, yaitu sekitar 4-5 bulan. Pedet harus dirawat secara intensif dan sehat agar menjadi calon induk yang berkualitas (Hidajati 1998). Penanganan pedet awal kelahiran sangat diperlukan agar pedet dapat tumbuh dan berkembang sebagaimana mestinya.

Hijauan indigofera adalah pakan ternak yang cocok dikembangkan di Indonesia karena tanah terhadap air dan suhu panas (Hassen et al.,
2007). Selain itu, pertumbuhannya sangat singkat, adaptif terhadap tingkat kesuburan rendah, mudah, dan murah pemeliharaannya. Indigofera mengadung protein cukup tinggi yaitu setara dengan alfalfa, berkisar 23-27\% yang optimal bagi ternak. Tepung daun Indigofera zollingeriana kasar sekitar 23,40$27,60 \%$, NDF 51,16-59,97\%, kecernaan in vitro bahan organik berkisar 77,46-80,47\% Abdullah dan Suharlina (2010). Selain itu, tepung Indigofera zollingeriana memiliki kandungan mineral yang cukup untuk pertumbuhan optimal ternak, yaitu Ca 1,78\%, P 0,34\%, Mg 0,51\% (Abdullah, 2010). kecernaan bahan 
kering tepung indigofera sebesar $68.21-73.15 \%$ dan koefisien cerna bahan organik sebesar 65.33-70.64\%.

Kualitas suatu pakan akan terlihat jelas jika dilakukan pengamatan evaluasi kecernaan pakan. Pakan, Ternak, dan Lingkungan Mempengaruhi Kecernaan (McDonald et al. 2002). Penelitian ini bertujuan untuk mengetahui kecernaan bahan kering, bahan organic, dan serat kasar pada pedet

\section{MATERI DAN METODE}

\section{Materi}

Penelitian ini tentang pengaruh pemberian tepung indigofera terhadap kecernaan bahan kering, bahan organik, dan serat kasar pada pedet dilakukan di PT Waluyo Wijaya Farm Bogor, Jawa Barat menggunakan pedet lepas sapih sebanyak 9 ekor.

Pakan yang diberikan adalah tepung indigofera yang berasal dari cianjur selatan, Rumput gajah dan kosentrat. Hasil analisa pakan dapat dilihat pada Tabel 1.

Tabel 1 Hasil analisa proksimat tepung indigofera dalam bahan kering

\begin{tabular}{ccll}
\hline $\begin{array}{c}\text { Bahan } \\
\text { Pakan }\end{array}$ & Parameter & Satuan & Hasil \\
\hline Indigofera & Total Air & g/ 100 g & 11,29 \\
& Protein & g/ 100 g & 22,67 \\
& Lemak & g/ 100 g & 2,77 \\
& GE & Kcal & 3759 \\
& SK & g/ 100 g & 15,27 \\
& Abu & g/ 100 g & 16,66 \\
& Ca & g/ 100 g & 1,91 \\
& P & g/ 100 g & 0,25
\end{tabular}

Keterangan : BK: Bahan Kering, PK: Protein Kasar, SK: Serat Kasar, LK: Lemak Kasar, GE, SK, ABU, CA, P.

Desain kandang pedet adalah kandang individu dengan format tail to tail. Peralatan yang digunakan antara lain: timbangan pakan, skop, cangkul, ember. dan lain lain. Pakan pada penelitian ini digunakan tepung indigofera, rumput gajah, dan kosentrat. Ternak yang digunakan adalah pedet dengan jumlah 9 ekor. dialokasikan secara acak 3 perlakuan dan setiap perlakuan mempunyai 3 ulangan. pedet tersebut dipelihara selama 15 hari secara intensif (preliminary) dan 3 hari berikutnya dilakukan koleksi total.

\section{Perlakuan}

R0 (100\% rumput gajah + kosentrat), R1(60\% hijauan $+(35 \%$ kosentrat+ $5 \%$ indigofera $)$, R2 $260 \%$ hijauan+(30\% kosentrat+ $10 \%$ indigofera)

\section{Rancangan Percobaan}

Rancagan percobaan dalam penelitian ini adalah Rancangan Acak Lengkap (RAL). Model rancangan menurut Hanafiah (2001) adalah sebagai berikut:

Yij : $\mu+\mathrm{Ti}+\varepsilon \mathrm{ij}$

Keterangan :

i

j $\quad: 1,2,3$

Yij $\quad$ : pengaruh perlakuan ke-I dan blok ke-j

$\mu$ : nilai tengah umum dari hasil pertumbuhan tanaman

$\mathrm{Ti} \quad$ : pengaruh perlakuan ke-i

eij : pengaruh galat pada perlakuan ke-I dan kelompok ke-j

\section{Peubah yang Diamati}

Peubah yang diamati terdiri atas: 1) Kecernaan Bahan Kering, 2) Kecernaan Bahan Organik, 3) Kecernaan Serat Kasar.Kecernaan nutrien diukur dengan rumus yang dikembangkan oleh Harris et al. (1970), Sebagai berikut: Menghitung Kecernaan Bahan Kering dengan konsumsi bahan kering dikurangi dengan bahan kering feses dibagi konsumsi bahankering. Kecernaan bahan organik diperoleh dengan cara menghitung konsumsi bahan organik pakan dikurangi dengan bahan organik feses dan dibagi konsumsi bahan organik pakan kemudian dikali 100\%.Kecernaan serat kasar diperoleh dengan cara menghitung konsumsi serat kasar pakan dikurangi dengan serat kasar feses dan dibagi konsumsi serat kasar pakan kemudian dikali $100 \%$.

\section{Analisis Data}

Analisis data di penelitian ini menggunakan sidik ragam anova dan jika data berpengaruh nyata maka analisis dilanjutkan dengan uji lanjut Duncan menggunakan bantuan piranti program. 


\section{Prosedur Pelaksanaan}

Pada penelitian ini menggunakan 9 ekor pedet lepas sapih. Setelah itu persiapan ketersedian pakan ternak yang akan diberikan. Pemeliharaan / penelitian ini berlangsung selama 3 minggu. 2 minggu untuk adaptasi pakan 1 minggu untuk koleksi feses. Koleksi feses dilakukan selama 5 hari selama 24 jam kemudian ditimbang sebagai bobot segar setalah itu di ambil sampel lalu dikeringkan di bawah matahari. Setelah feses kering feses tersebut di bawa ke lab Ilmu Nutrisi dan Teknologi Pakan Institut Pertanian Bogor.

\section{HASIL DAN PEMBAHASAN}

Kecernaan bahan makanan adalah bahan makanan yang dicerna disaluran pencernaan ternak dan tidak dibuang bersama feses, bagian ini diasumsikan terserap dalam tubuh ternak (McDonald et al., 1995). Kecernaan pedet terhadap hijauan adalah 65-85\% Parakkasi (1999), sedangkan bila konsentrat ditingkatkan, kecernaannya akan meningkat. Sutardi (1980) menambahkan bahwa, keberadaan pakan dalam alat pencernaan ruminansia akan mengalami perubahan kimia, biologi dan fisik. Selain itu, setiap jenis ternak memiliki kemampuan yang berbeda dalam mendegradasi pakan, sehingga mengakibatkan perbedaan kecernaan dalam rumen.

\section{Kecernaan bahan Kering}

Kecernaan bahan kering merupakan indikator derajat kecernaan pakan pada ternak rataan konsumsi dan kecernaan bahan kering pada Pedet FH yang diberi perlakuan pakan yang mengandung tepung indigofera, disajikan pada Tabel 2.

Tabel 2 Rataan Kecernaan Bahan Kering (\%)

\begin{tabular}{cc}
\hline Perlakuan & Kecernaan BK\% \\
\hline RO & $63,75 \pm 2,74$ \\
R1 & $64,44 \pm 4,73$ \\
R2 & $62,70 \pm 3,17$ \\
\hline
\end{tabular}

Keterangan: $\quad$ R0 $\quad(100 \%$ rumput gajah + kosentrat), R1 $60 \%$ hijauan+ $(35 \%$ kosentrat+ $5 \%$ indigofera), R2 $60 \%$ hijauan+ $(30 \%$ kosentrat+ $10 \%$ indigofera)

Penambahan tepung indogofera pada pedet memberikan pengaruh yang tidak berpengaruh nyata $(P>0,05)$ terhadap kecernaan bahan kering pada pedet FH (Tabel 4). Kecernaan bahan kering pada penelitian ini berkisar antara 62,70-64,4\%. Nilai kecernaan bahan kering pada penelitian ini masih berada kisaran ratarata kecernaan. Kecernaan pedet terhadap hijauan berkisar antara 65-85 \% Parakkasi (1999). Terilihat bahawasanya kecernaan bahan kering penelitian ini masih dikatakan normal. Kecernaan bahan kering pada indigofera berkisar 67,50\%; dan kecernaan bahan organic berkisar 60,32\% Abdullah (2010).Pada penelitian yang berbeda rataan kecernaan bahan kering adalah 57,34\% Elita (2006) lebih rendah dari pada penelitianini. Pada penelitian yang berbeda pula Nuswantara et al. (2005) menghasilkan kecernaan bahan kering 58,75\%.

\section{Kecernaan Bahan Organik}

Rataan dan kecernaan bahan Organik pada Pedet FH yang telah diberikan perlakuan pakan yang ditambahkan dengan tepung indigofera, disajikan pada Tabel 3.

Tabel 3 Rataan Kecernaan Bahan Organik

\begin{tabular}{lc}
\hline \multicolumn{1}{c}{ Perlakuan } & Keceernaan BO\% \\
\hline RO & $66,72 \pm 2,31$ \\
R1 & $67,50 \pm 4,32$ \\
R2 & $66,86 \pm 2,53$ \\
\hline Keterangan: R0 $\quad(100 \%$ rumput gajah + \\
kosentrat), R1(60\% hijauan+(35\% kosentrat+ $5 \%$ \\
$\begin{array}{l}\text { indigofera), R2(60\% hijauan+(30\% kosentrat+ } 10 \% \\
\text { indigofera) }\end{array}$
\end{tabular}

Bahan organik adalah selisih dari bahan kering dikurangi kadar abu. Kecernaan bahan organik menunjukkan jumlah nutrien protein, lemak, dan karbohidrat yang dapat dicerna oleh ternak. Nilai kualitas suatupakan dapat dittentukan dari nilai kecernaan bahan organic (Sutardi 1980) Penelitian ini menghasilkan data kecernaan bahan organik dengan hasil yang tidak berpengaruh nyata $(P>0,05)$ sebesar 66,7$67,5 \%$. Kecernaan bahan kering sejalan dengan kecernaan bahan organik, tinggi atau rendahnya kecernaan bahan kering akan berpengaruh positif terhadap kecernaan bahan organik. Kecernaanpedet terhadap hijauan berkisar antara 65-85 \%Parakkasi (1999). Hal ini menunjukkan kecernaan bahan Organik penelitian ini normal. Elita (2006) Rataan kecernaan bahan organik adalah 60,74\%. Pada penelitian yang berbeda kecernaan bahan organik sekitar $72.30 \%$ Suryani et al (2014). 


\section{Kecernaan Serat Kasar}

Rataan kecernaan serat kasar pada Pedet FH yang telah diberikan perlakuan pakan yang ditambahkan dengan tepung indigofera, disajikan padaTabel 4 .

Tabel 4 Rataan Kecernaan Serat Kasar.

\begin{tabular}{cc}
\hline Perlakuan & Keceernaan SK \% \\
\hline RO & $69,85 \pm 1,81$ \\
R1 & $67,77 \pm 6,24$ \\
R2 & $63,62 \pm 4,65$ \\
\hline
\end{tabular}

Keterangan: $\quad$ R0 $\quad(100 \%$ rumput gajah + kosentrat), R1 $(60 \%$ hijauan $+(35 \%$ kosentrat+ $5 \%$ indigofera), R2 (60\% hijauan+(30\% kosentrat+ 10\% indigofera)

Sidik ragam Kecernaan serat kasar pada penelitian ini tidak berbeda nyata $(P>0,05)$ dengan kisaran 63,6-69,8\% sesuai dengan kecernaan serat kasar hijauan yaitu 65-85 \% (Parakkasi, 1999). hal ini dikarenakan pedet yang digunakan untuk penelitian adalah pedet lepas sapih yang sudah diajarkan mengkonsumsi hijauan dan rumenya pun sudasedikitberkembang. Kisaran kecernaan serat kasar yaitu antara 30\%-80\% dari total serat yang dikonsumsi oleh ternak Marpaung (2011). Berdasarkan hal tersebut, maka nilai kecernaan serat kasar pakan cukup baik, yaitu $67,7 \%$. Pada penelitian yang berbeda kecernaan serat kasar berkisar rata-rata $63,34 \%$ Suryani et al (2014).

\section{KESIMPULAN DAN IMPLIKASI}

\section{Kesimpulan}

Pemberian tepung indigofera pada pedet $\mathrm{FH}$ tidak berpengaruh nyata terhadap kecernaan Bahan Kering, Bahan Organik, dan Serat Kasar pada pedet FH. Pada penelitian ini menunjukan bahwa tepung indigofera dapat dijadikan sebagai salah subtitusi sumber protein pakan ternak (pedet) karena protein indigofera yang tinggi $22,67 \%$

\section{Implikasi}

Perlu penelitian lebih lanjut tentang pengaruh pemberian Tepung Indigofera lepas sapih terhadap kecernaan bahan kering, bahan organik, dan serat kasar pada pedet lepas sapih.

\section{DAFTAR PUSTAKA}

Abdullah L. 2010. Laporan Akhir Program Insentif Terapan: Pengembangan Produk Hay, Tepung dan Pellet Daun Indigofera cordifolia sebagai Alternatif Sumber Protein Murah Pakan Kambing Perah. [Skripsi]. LPPM, IPB, Bogor.

Abdullah L, Suharlina. 2010. Herbage yield and quality of two vegetative parts of Indigofera at different time of first regrowth defoliation. Med. Pet. 33:44- 49.

Abdullah L. 2010. Herbage production and quality of shrub Indigofera treated by different concentration of foliar fertilizer. Med Pet 33(3): 169-175

Elita I. 2006. StudiPerbandinganUmum dan Kecernaan Pakan pada Kambing dan DombaLokal. [skripsi]. Fakultas Peternakan, Institut Pertanian Bogor, Bogor

Hassen AP, Pieterse A, Rethman NFG. 2004. Effect of pre-lanting seed treatment on dormancy breaking and germination of Indigofera accessions. $J$ Tropical Grasslands38 : 154-157.

Hassen A, Rethman NFG, van Niekerk WA, Tjelele TJ. 2007. Influence of season/year and species on chemical composition and in vitro digestibility of five Indigofera accession. J. Anim. Sci 136 : 312-322.

McDonald P, Edwards RA, Greenhalgh JFD, Morgan CA. 2002. Animal Nutrition. London (UK): Prentice Hall

Nuswantara, L. K. M. Soejono, R. Utomo dan B. P. Widyobroto. 2005. Kecernaan nutrien ransum prekursor nitrogen dan energi tinggi pada sapi perah yang diberikanpakan basal jeramipadi. J. Indon. Trop. Anim. Agric. 30 (3).

Parakkasi A. 1999. Nutrisi dan Makanan Ternak Ruminan. Universitas Indonesia Press, Jakarta.

Sutardi T. 1980. Ketahanan protein bahan makanan terhadap degradasi oleh mikrobarumen dan manfaatnya bagi peningkatan produktivitas ternak. Proceeding Seminar dan Penunjang 
Peternakan. Lembaga Penelitian Peternakan, Bogor.

Suryani NN, Mahardika IG, Putra S, Sujaya N. 2014. SifatFisik dan KecernaanRansumSapi Bali Yang MengandungHijauanBeragam.
ProsidingSemnas III HITPI, Bukittinggi Sumatera Barat.

Van Soest PJ. 1994. Nutrition Ecology of The Ruminant. Ed ke-2. New York (US): 0 and B Books, Inc. Corvalis, Cornell University Press. 
